\title{
Tourist purchases in a destination: what leads them to seek information from digital sources?
}

\author{
Alba García-Milon, Cristina Olarte-Pascual, Emma Juaneda-Ayensa \\ and Jorge Pelegrín-Borondo \\ Universidad de La Rioja, Logroño, Spain
}

\begin{abstract}
Purpose - In a context where retail stores are closing down and high streets are declining, the purpose of this paper is to analyse on-site shopping by tourists. This work identifies the drivers that lead tourists to use digital information sources at the beginning of the shopping process. Understanding these drivers can help destination managers and retailers encourage tourists to shop.

Design/methodology/approach - A personal survey was conducted in a Spanish city noted for its shopping facilities (Logroño), using a sample of 430 tourists with purchase intention. The survey was designed based on the extended unified theory of acceptance and use of technology (UTAUT2) model. A multivariate analysis, based on structural equation modelling, was carried out using partial least squares (PLS), based on variance. Findings - The study's finding is that performance expectancy, effort expectancy, social influence, facilitating conditions and habit influence intention to use digital sources of information to make purchases in a destination. Tourists prioritise utilitarian over hedonic motivations in the intention to use digital sources of information in tourist shopping.

Originality/value - It has been recognised that tourists are the perfect target to revitalise on-site shopping and, therefore, destinations must provide attractive shopping experiences from the outset. Prior to purchase, the search for available information is the first stage of the tourist shopping journey. Although many studies have analysed tourist shopping behaviour, none have focused, using the UTAUT2, on the digital information sources tourists consult pre-purchase. This research develops understanding of tourist shopping behaviour in this new technological context. This can help retailers/destinations provide better services and optimise the shopper's experience from the first stage of the process.
\end{abstract}

Keywords Tourist shopping, Digital information sources, Technology, UTAUT2, Logroño

Paper type Research paper

\section{Introduction}

Retail shops and on-site shopping are endangered; according to Coresight Research, in the United States of America (USA) more than 9,300 stores shut down in 2019, a very significant increase on the 5,800 that closed in 2018 (Coresight Research, 2020); also, in Spain, an average of 23 retail stores have closed down every day since 2015 (Montero, 2019). In this context, tourists have been recognised as the perfect target public to maintain the high street vitality (García-Milon et al., 2021; Lindberg et al., 2019; Rabbiosi, 2015). Tourist shopping provides

(C) Alba García-Milon, Cristina Olarte-Pascual, Emma Juaneda-Ayensa and Jorge Pelegrín-Borondo. Published in European Journal of Management and Business Economics. Published by Emerald Publishing Limited. This article is published under the Creative Commons Attribution (CC BY 4.0) licence. Anyone may reproduce, distribute, translate and create derivative works of this article (for both commercial and non-commercial purposes), subject to full attribution to the original publication and authors. The full terms of this licence may be seen at http://creativecommons.org/licences/by/4.0/legalcode

This research has been made possible thanks to the support of the Extraordinary Chair of Commerce of the University of La Rioja and the Logroño City Council and funded by a predoctoral contract FPI-UR 2019. The authors would also like to acknowledge the COBEMADE research group at the University of La Rioja (reference REGI 2020/40) and the HYPERLINK "https://www.linguee.co/ingles-espanol/traduccion/ autonomous+community.html" autonomous community of La Rioja through the program RIS3 Ref:CAR PID2019-105764RB -I00.
Tourist

purchases in a destination

Received 2 September 2019 Revised 23 December 2019 20 February 2020 6 November 2020

30 December 2020

8 January 2021

2 April 2021

Accepted 13 April 2021

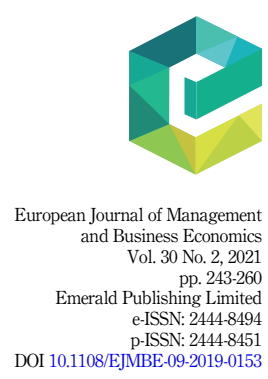


EJMBE 30,2 benefits for destinations; it is of significant interest as it contributes to a positive image (Jin et al., 2017; Tosun et al., 2007) and is an important income source (Chang et al., 2006; Jin et al., 2017). Fortunately, in the last decades, shopping at destinations has become one of the most important activities that the tourist undertakes (Chen, 2013; Lloyd et al., 2011; Silva et al., 2019; Yüksel, 2007). For many, shopping is an essential element and, without it, their tourism experience would be incomplete (Brochado et al., 2018; Chang et al., 2006; Chen, 2013; Timothy and Butler, 1995; Tosun et al., 2007). In some cases, it can be the main motivation for travel (Timothy and Butler, 1995; Wong and Wan, 2013). Moreover, tourists derive great value from the satisfaction and pleasure associated with their purchases and by experiencing local culture (Hsieh and Chang, 2006; Way and Robertson, 2013).

But what triggers tourist purchasing in a destination? In tourism, as in other consumer scenarios, after identifying a need, the tourist's first step is to search out the shopping possibilities (Coromina and Camprubí, 2016; Gursoy and McCleary, 2004). For this reason, consumer information search has been considered to be among the most influential factors in the purchase decision-making process (Akalamkam and Mitra, 2018). Tourists today can consult many information sources, from the traditional, such as friends, advertising and travel guides, to sources provided by new technologies and the Internet, which make it possible to access information about any product or service anytime and anywhere (Piotrowicz and Cuthbertson, 2014; Rodríguez-Torrico et al., 2017). Consumers now habitually use multidevices (e.g. smartphones, tablets, wearables) to access the Internet (Fritz et al., 2017). There are $4.021 \mathrm{tn}$ Internet users worldwide (Ditrendia, 2018). This new technological context has changed tourists' behaviours, giving rise to practices where, in the pre-purchase stage, tourists consult various information sources (García-Milon et al., 2019; Verhoef et al., 2015). In particular, tourists mainly use digital devices, which are now considered indispensable, and essential for touristic activities (Rodríguez-Torrico et al., 2020).

To promote such a significant activity as shopping at destinations, it is crucial to understand tourists' purchasing behaviours from the first stage of the process, that is, the search for information. This understanding can help destinations develop tools to encourage tourists to embark on the process. Although many studies have analysed tourist shopping behaviour, none have focused on the tourist's consultation of digital information sources as the start point of the process. To bridge this gap, we have set as the main aim of this study the identification of the drivers for tourists in their search for information, using digital devices, in their purchases in destinations. As the use of digital information sources is a behaviour clearly related to the acceptance of new technologies, we apply unified theory of acceptance and use of technology2 (UTAUT2) (Venkatesh et al., 2012). This is a model that has been tested in various technological contexts and has been validated in several research papers (e.g. Gupta et al., 2018; Macedo, 2017; Morosan and DeFranco, 2016). Moreover, their developers encourage its application to new technological behaviours (Venkatesh et al., 2012), our case, the use of digital information sources in tourist shopping is a behaviour clearly related to the acceptance of new technologies in a new context. The present study contributes to the tourism/retail literature by setting three specific objectives: (1) to provide a hierarchy of those aspects most important to tourists when seeking shopping information, (2) to highlight the important elements that technological sources of information must provide the tourist and (3) to make an initial contribution to the understanding of the tourist's purchase behaviour at the first stage of the process and to call for further research.

\section{Theoretical framework}

As has been noted, shopping during a tourist visit adds value to the tourist's experience (Hsieh and Chang, 2006; Way and Robertson, 2013) and to the destination (Chang et al., 2006; Tosun et al., 2007). The concept of shopping tourism was introduced, as a leisure activity, for 
the first time into the academic arena by Jansen-Verbeke (1991), where the purchases are inessential (Martin and Mason, 1987). It was not until 2005 that Timothy provided a definition of the concept of shopping tourism in the research field: shopping tourism is an activity in which shopping is the main motivation to travel or the main element of the tourist experience (Timothy, 2005). This definition has been widely accepted by numerous scholars (e.g. Choi et al., 2016; Jin et al., 2017; Rabbiosi, 2011). However, this paper focuses on a practice more widely undertaken by tourists: tourist shopping, defined as a secondary or additional activity undertaken during a trip (García-Milon et al., 2021; Rabbiosi, 2011) in which tourists seek, select and buy goods (Jin et al., 2017). Information seeking is integrated into tourist shopping (Jin et al., 2017), and is the first step of the complete purchasing process of a tourist in a destination or tourist shopping journey (García-Milon et al., 2020).

Recent technological advances have created a revolution in retail by broadening the options for obtaining information. New channels (e.g. mobile channels, Internet, social networks and chat) and devices (e.g. smartphones, tablets, smartwatches, wearables and televisions) have precipitated changes in consumer purchasing habits and behaviours (Verhoef et al., 2015). Some years ago, consumers had access only to offline channels (i.e. stores and other physical resources provided by retailers) to obtain information; new technologies have now created self-informed consumers. These technologies allow consumers to inform themselves anywhere, and at any time, in an autonomous way (Melero et al., 2016; RodríguezTorrico et al., 2017). The intangibility of tourism prompted tourists to depend on digital information sources (Koo et al., 2015), and they are regarded as helpful tools when planning a trip (Lee et al., 2019). Due to their initial unfamiliarity with the shopping offer, tourists need information from the available information sources to begin the tourist shopping journey (García-Milon et al., 2020). Here, digital sources of information allow an exponential growth in tourists' autonomy as they can obtain information on the go (Rodríguez-Torrico et al., 2017).

New challenges have arisen in tourism research that need to be addressed to satisfy highly connected tourists (Kozak et al., 2018). Tourism is one of the sectors that needs a most rapid and convenient incorporation of new technologies to meet the demands of tourists, who are increasingly more informed and "hyperconnected" (Castañeda et al., 2019; Cohen et al., 2014). In the understanding of tourists' shopping behaviour, the intention to use digital information sources is crucial as it is the first stage of the process. Consequently, this paper identifies the antecedents that lead tourists to consult digital information sources.

\section{Hypotheses development}

In the present study, the extended UTAUT2 model (Venkatesh et al., 2012) has been employed. This model identifies the key elements in the consumer's acceptance and use of technologies (Venkatesh et al., 2003, 2012; Venkatesh and Davis, 2000). The developers of the UTAUT2 do not suggest that the model should be limited to narrow contexts, indeed they encourage researchers to extend it to different fields and situations (Venkatesh et al., 2012). Therefore, the UTAUT2 model could contribute to the understanding of important technological phenomena such as, as in this case, the use of digital device-based information sources, a newly emerged technology-based behaviour (Venkatesh et al., 2012). The UTAUT2 (1) has higher explanatory power than other technology acceptance models (Pan and JordanMarsh, 2010; Verdegem and De Marez, 2011); (2) focuses on consumers and provides an understanding of their acceptance of new technologies and (3) has a strong empirical basis in a variety of disciplines and subjects (e.g. Alalwan et al., 2017; Baptista and Oliveira, 2015; Morosan and DeFranco, 2016; Tamilmani et al., 2019).

The model was developed from the UTAUT model (Venkatesh et al., 2003), which is the synthesis of eight theoretical models used in the behaviour literature (Ajzen, 1991; Davis et al., 1989; Moore and Benbasat, 1991; Thompson et al., 1991). The UTAUT2 proposes that 
EJMBE 30,2

\section{6}

consumers' intentions to use technologies are formed by seven factors (Figure 1): (1) performance expectancy, (2) effort expectancy, (3) social influence, (4) facilitating conditions, (5) hedonic motivation, (6) price-value and (7) habit (Venkatesh et al., 2012). In the following subsections, these factors are discussed in the development of the research hypotheses (Figure 1):

\section{Performance expectancy}

Performance expectancy has been defined as the degree to which the consumer (in our case, tourist) considers that using sources of information to make purchases will be beneficial to his or her performance (Venkatesh et al., 2003, 2012). This factor is considered essential in new technology acceptance by consumers (Venkatesh et al., 2003). In general terms, if consumers perceive that using new technologies is advantageous and useful for their activities, they will be more motivated to use and accept them (Alalwan et al., 2017; Davis et al., 1989; Venkatesh et al., 2003). Previous studies have shown the positive effect of performance expectancy on behavioural intention (e.g. Alalwan et al., 2017; Baptista and Oliveira, 2015; Macedo, 2017; Venkatesh et al., 2003), and that it is an influencer of technology-use behaviour during the shopping process (Mosquera et al., 2018). In the tourism field, it has been determined that performance expectancy is significant, and that it is an antecedent of the acceptance of technologies and innovations (Herrero et al., 2017; Ibukun et al., 2016; Uphaus et al., 2019). Taking this into account in the context of this study, we posit the following hypothesis:

H1. Performance expectancy has a positive effect on the tourist's intention to use digital sources of information in tourist shopping.

\section{Effort expectancy}

Effort expectancy has been defined as the degree of ease associated with using sources of information to make a purchase in a destination (Venkatesh et al., 2003, 2012). In the existing

Figure 1.

Measurement model of the influence of the UTAUT2 factors on the tourist's intention to use digital information sources

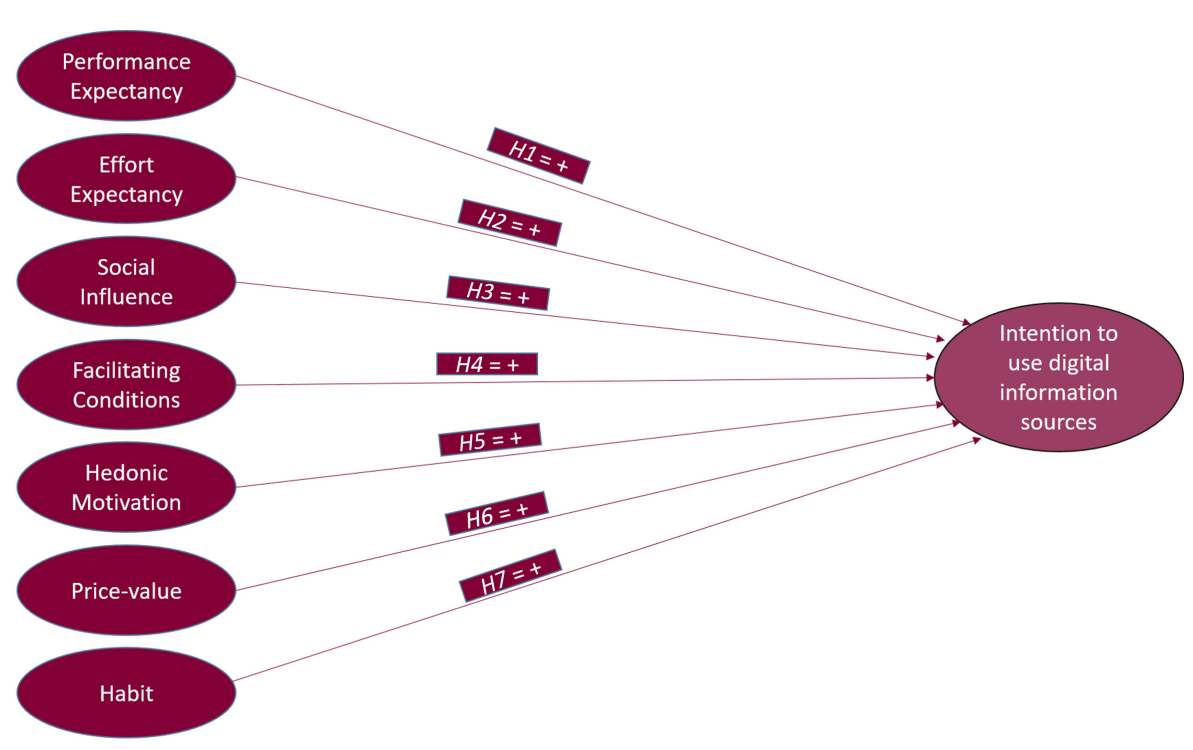

Source(s): Adapted from Venkatesh et al., 2012 
models, there are three effort expectancy-related constructs: perceived ease of use (TAMtechnology acceptance model / TAM2), complexity (MPCU-model of PC utilisation) and ease of use (IDT-innovation diffusion theory) (Venkatesh et al., 2003). The predictive power of effort expectancy for behavioural intention is widely accepted (e.g. Baptista and Oliveira, 2015; Macedo, 2017; Raman and Don, 2013), including the tourism field (Ibukun et al., 2016; Uphaus et al., 2019). To take forward the knowledge of this factor in the context of using online sources of information to make purchases at a tourist destination, we propose the following hypothesis:

H2. Effort expectancy has a positive effect on the tourist's intention to use digital sources of information in tourist shopping.

\section{Social influence}

Social influence has been defined as the degree to which tourists perceive that people who are important to them believe they should use sources of information to make purchases (Venkatesh et al., 2003, 2012). Social influence is defined as a subjective norm in the TRA (theory of reasoned action), the TAM2, the TPB (theory of planned behaviour)/the DTPB (decomposed theory of planned behaviour) and the C-TAM-TPB (combined TAM and TPB), as social factors in the MPCU, and is used as a direct determinant in behavioural intention (Davis et al., 1989; Moore and Benbasat, 1991; Venkatesh et al., 2003). People close to the consumer can affect his/her awareness of, and attitude towards, technologies (Alalwan et al., 2017). In general, the predictive power of social influence for behavioural intention is accepted (Ibukun et al., 2016; Macedo, 2017; Raman and Don, 2013; Venkatesh et al., 2003). It has also been considered as an important factor in tourists' purchases (Gupta et al., 2018). Taking into account the findings of previous studies, we posit the following hypothesis about social influence:

H3. Social influence has a positive effect on the tourist's intention to use digital sources of information in tourist shopping.

\section{Facilitating conditions}

Facilitating conditions refer to the degree to which an individual considers that there is an organisational and technical structure to support him/her to use sources of information to make purchases in destinations (Venkatesh et al., 2003, 2012). The facilitating conditions factor has its antecedents in constructs developed in earlier theories: control of perceived behaviour (TPB / DTPB, C-TAM-TPB), facilitating conditions (MPCU) and compatibility (IDT) (Venkatesh et al., 2003). The factor is important because, when the consumer tries to use a technology to perform a certain task, it will be impossible to carry it out if the necessary conditions for doing so are absent (Morosan and DeFranco, 2016; Venkatesh et al., 2012). Facilitating conditions are important in predicting behaviour towards technologies, in general (Macedo, 2017; Raman and Don, 2013; Venkatesh et al., 2003, 2012), and in the tourism field, in particular (Ibukun et al., 2016). Given this background, we propose the following hypothesis:

H4. Facilitating conditions have a positive effect on the tourist's intention to use digital sources of information in tourist shopping.

\section{Hedonic motivation}

The present study characterises hedonic motivation as reflecting the fun or pleasure derived from using sources of information to make a purchase (Venkatesh et al., 2012). Consumers perceive that enjoyment is a very important determinant in relation to acceptance and use of 
EJMBE 30,2

\section{8}

technology, given its direct role in behaviour (Brown and Venkatesh, 2005; Childers et al., 2001; Ibukun et al., 2016). It is a significant indicator of behavioural intention (Baptista and Oliveira, 2015; Macedo, 2017; Morosan and DeFranco, 2016; Raman and Don, 2013; Venkatesh et al., 2012). Moreover, hedonic motivation has been seen as an important factor when using tourism-related technologies (Escobar-Rodríguez and Carvajal-Trujillo, 2014; Ibukun et al., 2016; Uphaus et al., 2019). Taking into account the previous research, we propose the following hypothesis in relation to hedonism and the use of digital information sources in tourist shopping:

H5. Hedonic motivation has a positive effect on the tourist's intention to use digital sources of information in tourist shopping.

\section{Price-value}

Price-value is understood to be the consumer's awareness of the perceived benefits of using sources of information in relation to the monetary cost of using them (Dodds, 1991; Venkatesh et al., 2012). When the benefits of using a technology are greater than its monetary cost there will be a positive effect on the price-value variable (Venkatesh et al., 2012). Some studies have shown that its influence on behavioural intention towards technologies is not significant (e.g. Baptista and Oliveira, 2015; Macedo, 2017), although others have concluded it is a good indicator (e.g. Ibukun et al., 2016; Venkatesh et al., 2012). We propose the following:

H6. Price-value has a positive effect on the tourist's intention to use digital sources of information in tourist shopping.

\section{Habit}

Habit is the degree to which tourists automatically display learnt behaviour in terms of using sources of information to make purchases in destinations (Venkatesh et al., 2012). Previous experiences influence beliefs and, consequently, future behaviour (Ajzen and Fishbein, 2005). Previous research has found that habit has a significant, positive effect on behavioural intention (Baptista and Oliveira, 2015; Ibukun et al., 2016; Macedo, 2017; Morosan and DeFranco, 2016; Venkatesh et al., 2012). Other studies also support the positive effect of habit in technology use in tourism activities (Cássia de Moura et al., 2017; Castañeda et al., 2019). Taking this into account, we put forward the following hypothesis:

H7. Habit has a positive effect on the tourist's intention to use digital sources of information in tourist shopping.

\section{Methodology}

Data collection and sample

To test our hypotheses, after evaluating important commercial and tourism aspects, an urban tourism destination was chosen. The city selected had to meet the following criteria: (1) to havea homogeneous central commercial zone; (2) to promote shopping as a motivation to visit the destination; (3) to have typical, local independent shops with high value for non-residents; (4) to have a recognisable, attractive shopping offer; and (5) to be readily accessible from other cities and have good tourist infrastructure. As a result, Logroño (Spain) was chosen. Logroño, unlike other larger cities that integrate a variety of districts, has a distinct central zone with a range of unique shops. Its excellent shopping facilities are used by the public administration to promote tourism: it was officially recognised as the first Spanish "City of Commerce" in 1997. In addition, it was nominated to become the first Commercial City of Europe in 2020 (EFE, 2016). Logroño is a medium-sized urban destination located at a strategic point in the northern part of Spain. It is
} 
the capital of the La Rioja region, renowned worldwide for its wine (Denomination of Origin Rioja), which accounts for $47 \%$ of Spanish wine production (Nielsen, 2014).

A personal survey was conducted in the city of Logroño using a sample of 430 tourists (marginal error $4.72 \%$, at a confidence interval level of $95 \%$ ). As our objective was to analyse intention to use digital sources of information to make purchases, we chose only tourists with purchase intention, asking an initial filter question. To obtain a diverse sample of tourists, three locations were chosen for the recruitment of potential respondents, all of them located near the city centre: the tourist information office, a three-star hotel and a four-star hotel (Logroño does not have any one-star or five-star hotels). The interviews were conducted soon after the tourists' arrivals, to assess their intentions before they began shopping. The respondents gave their consent to be interviewed and participate in the study. The data were collected by trained pollsters between December 2017 and March 2018.

\section{Measurement scales and data analysis}

The measure used was an 11-point Likert-type scale, from 0 (totally disagree) to 10 (totally agree), based on the UTAUT2 model proposed by Venkatesh et al. (2003, 2012). The variables used to test the model are shown in Table 1.

The survey questions were specifically framed to test the use of technology-based information sources, such as Google and other search engines, Tripadvisor and other forums and social networks. At the beginning of the survey, the interviewers stated that the purpose of the study was to measure the usage of digital sources of information.

Partial least squared (PLS) structural equation modelling (SEM) was used for the data analysis. PLS was selected because it is less sensitive to violation of assumptions of normality (Chin, 1998). Hair et al. (2011, p. 144) recommended using PLS-SEM "if the goal is predicting key target constructs or identifying key 'driver' constructs," as in our case. Similarly, other authors have suggested that PLS-SEM is appropriate when the research has a predictive aim (Shmueli et al., 2016) and an explanatory purpose (Henseler, 2018), as in the case of our study.

\section{Results}

Sample profile

Of the total sample of 430 tourists, $40.4 \%$ were male, and $59.6 \%$ were female, $95.6 \%$ were domestic tourists, and $4.4 \%$ international tourists. In terms of the number of nights spent in Logroño, $39.2 \%$ stayed for 1 night, $37 \%$ for 2 nights, $14.5 \%$ for 3 nights and $9.3 \%$ for more than 3 nights.

The results showed the types of product that the tourists intended to buy. Some $86.5 \%$ intended to buy packaged food or beverages. As previously noted, Logroño is the capital of La Rioja, a region known for its Denomination of Origin Rioja wine; this result confirms that this type of product is very important to the city and the region. It is not surprising, therefore, that wine is the main product purchased in the city. In the second place, we found that $36.4 \%$ intended to buy gifts and souvenirs, followed by $24.6 \%$ who intended to buy clothing, footwear and/or accessories.

\section{Evaluation of the measurement model}

First, the validity of the items was examined by assessing the standardised loadings $(>0.70)$ and $t$-values ( $>1.96$ ) (Figure 2). Although two indicators ( $\mathrm{FC} 4$ and Ha2) returned scores below 0.70 , there is flexibility if the indicator contributes to the validity of the factor (Hair et al.,2013) and has a $t$-value $>1.96$. The indicators met these conditions and, therefore, we included them in the model.

The measurement model was verified in terms of construct reliability (i.e. composite reliability and Cronbach's alpha), convergent validity and discriminant validity. Both the 
EJMBE 30,2

\section{0}

Effort expectancy (EE)

Social influence (SI)

Facilitating conditions ( $\mathrm{FC})$

Hedonic motivation (HM)

Price-value (PV)

Intention to use digital information sources (IUDIS)

Table 1.

Variable measurement items scale
Habit (Ha)

\begin{tabular}{lll}
\hline Construct & Items & Source \\
\hline Performance expectancy (PE) & $\begin{array}{l}\text { PE1. Using digital sources of information to buy is } \\
\text { very useful }\end{array}$ & $\begin{array}{l}\text { Adapted from } \\
\text { Venkatesh et al. (2003) }\end{array}$
\end{tabular}

PE2. Using them will increase the chance of buying what I want

PE3. Using them allows me to buy faster

PE4. Using them improves my purchasing performance

EE1. Learning how to use digital information sources to buy is easy

EE2. Using them is clear and understandable

EE3. It's easy to use them

EE4. Using them involves little effort

SI1. People important to me think I should use digital information sources in my purchases

SI2. People who influence me think I should use them

SI3. People whose opinions I value prefer that I use them

FC1. I have the resources necessary to use digital sources of information to buy

FC2. I have the knowledge to use them

FC3. They are compatible with each other

FC4. I can get help from others if I have difficulty using them

HM1. Using digital sources of information to buy is fun

HM2. It's nice

HM3. It's entertaining

PV1. Using digital sources of information to buy is reasonably priced

PV2. They are good value for money

PV3. At the current price, it's a good option to use them

Ha1. To use digital sources of information to buy is a habit for me

Ha2. I'm addicted to using them

Ha3. I think I should use them

Ha4. Using them is natural for me

I intend to use digital information sources to buy in the destination

I will probably use digital information sources to buy in the destination

I have decided to use digital information sources to buy in the destination
Adapted from

Venkatesh et al. (2012)

composite reliability and Cronbach's alpha were greater than 0.70 (Table 2). The convergent validity of the constructs was also confirmed, as the average variance extracted (AVE) is greater than 0.50 in all cases (Table 2). Discriminant validity was also confirmed (Table 3): the square root of the AVE of each construct was greater than the inter-construct correlations.

\section{Evaluation of the structural model}

We calculated the effect of the UTAUT2 factors on intention to use sources of information by tourists (Table 4). The $R^{2}$ showed a value of 0.474 , indicating that it explained $47.40 \%$ of the 

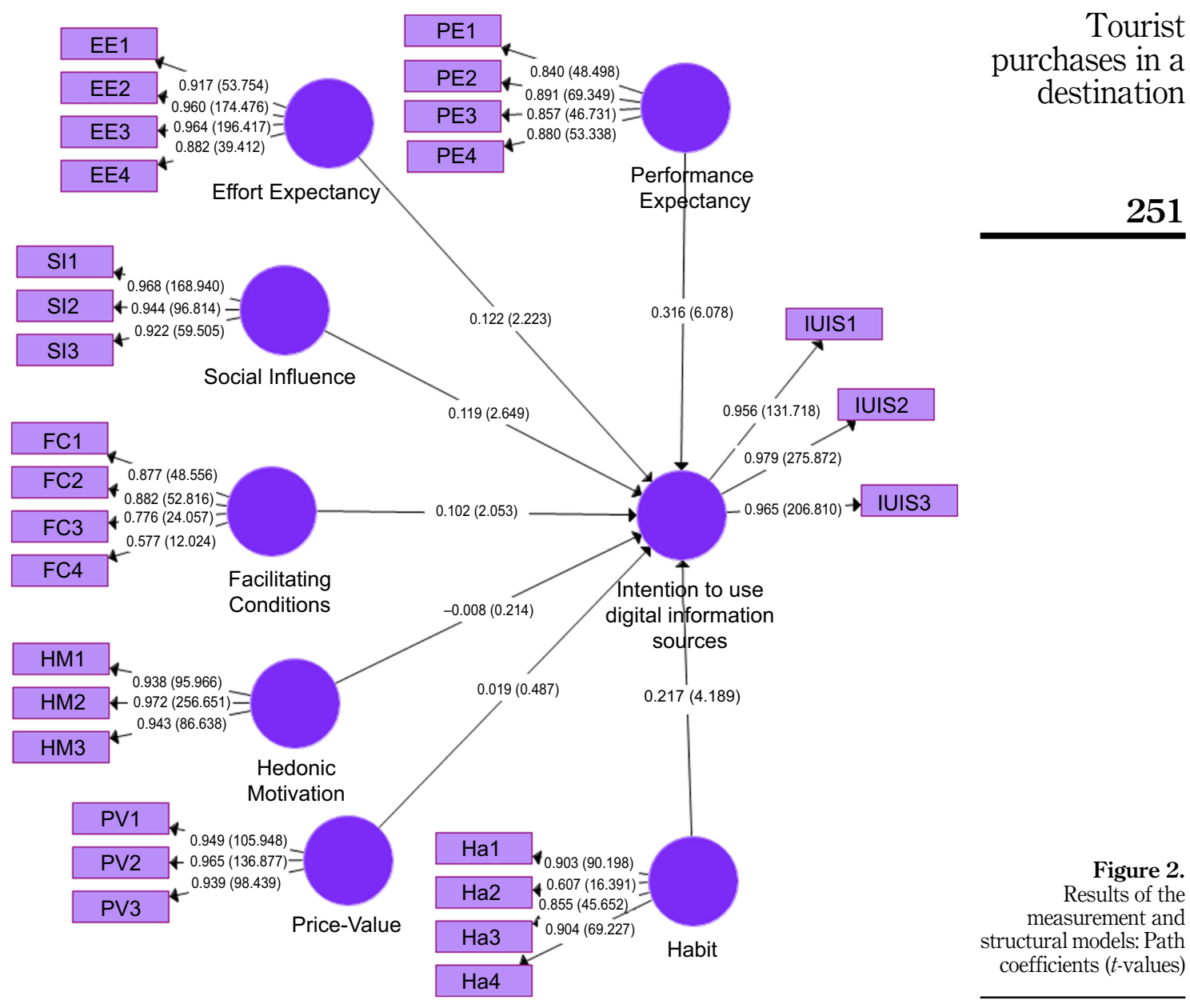

Figure 2.

Results of the measurement and structural models: Path coefficients ( $t$-values)

\begin{tabular}{lccc}
\hline Construct & $\begin{array}{c}\text { Composite } \\
\text { reliability }\end{array}$ & $\begin{array}{c}\text { Cronbach's } \\
\text { alpha }\end{array}$ & $\begin{array}{c}\text { Average variance extracted } \\
\text { (AVE) }\end{array}$ \\
\hline Performance expectancy & 0.924 & 0.891 & 0.752 \\
Effort expectancy & 0.963 & 0.948 & 0.867 \\
Social influence & 0.961 & 0.940 & 0.893 \\
Facilitating conditions & 0.864 & 0.786 & 0.620 \\
Hedonic motivation & 0.966 & 0.947 & 0.905 \\
Price-value & 0.966 & 0.947 & 0.904 \\
Habit & 0.894 & 0.841 & 0.683 \\
Intention to use information & 0.977 & 0.965 & 0.935 \\
sources & & &
\end{tabular}

Table 2.

Construct reliability and convergent validity 


\section{EJMBE 30,2}

\begin{tabular}{lcccccccc}
\hline Construct & PE & EE & SI & FC & HM & PV & HA & IUIS \\
\hline Performance expectancy (PE) & 0.867 & & & & & & & \\
Effort expectancy (EE) & 0.560 & 0.931 & & & & & & \\
Social influence (SI) & 0.371 & 0.247 & 0.945 & & & & & \\
Facilitating conditions (FC) & 0.449 & 0.731 & 0.187 & 0.788 & & & & \\
Hedonic motivation (HM) & 0.406 & 0.419 & 0.401 & 0.318 & 0.951 & & & \\
Price-value (PV) & 0.324 & 0.323 & 0.358 & 0.250 & 0.410 & 0.951 & & \\
Habit (Ha) & 0.605 & 0.556 & 0.431 & 0.392 & 0.479 & 0.363 & 0.827 & \\
Intention to use information sources & 0.608 & 0.526 & 0.383 & 0.443 & 0.363 & 0.304 & 0.570 & 0.967
\end{tabular}

Table 3.

Discriminant validity (IUIS)

Note(s): Diagonal elements (in italic) are the square root of the AVEs. Off-diagonal elements are the interconstruct correlations

Table 4.

Effects on the endogenous variables

\begin{tabular}{|c|c|c|c|c|c|}
\hline & $R^{2}$ & $\mathrm{Q}^{2}$ & Direct effects & $\begin{array}{c}p- \\
\text { value }\end{array}$ & $\begin{array}{l}\text { Support for } \\
\text { hypothesis }\end{array}$ \\
\hline $\begin{array}{l}\text { Intention to use information sources } \\
\text { (IUIS) }\end{array}$ & 0.474 & 0.415 & & & \\
\hline H1: Performance expectancy $\rightarrow(+)$ IUIS & & & $0.316^{* * * *}$ & 0.000 & Supported \\
\hline H2: Effort expectancy $\rightarrow(+)$ IUIS & & & $0.122^{*}$ & 0.015 & Supported \\
\hline H3: Social influence $\rightarrow(+)$ IUIS & & & $0.119 * *$ & 0.004 & Supported \\
\hline H4: Facilitating conditions $\rightarrow(+)$ IUIS & & & $0.102 *$ & 0.021 & Supported \\
\hline H5: Hedonic motivation $\rightarrow(+)$ IUIS & & & $-0.008 \mathrm{n} . \mathrm{s}$ & 0.418 & Non supported \\
\hline H6: Price-Value $\rightarrow(+)$ IUIS & & & $0.019 \mathrm{n} . \mathrm{s}$ & 0.303 & Non supported \\
\hline H7: Habit $\rightarrow(+)$ IUIS & & & $0.217^{* * * *}$ & 0.000 & Supported \\
\hline
\end{tabular}

Note(s): $* p<0.05 ; * * p<0.01 ; * * *<0.001$; n.s. not significant (based on a one-tailed Student's $t$ (4.999) distribution)

variance. The $\mathrm{Q}^{2}$ was 0.415 , which establishes that the model is highly predictive of the tourist's intention to use digital sources of information in his/her purchases (Hair et al., 2011). However, differences were found in the impact of the variables on intention to use sources of information, with five (performance expectancy, effort expectancy, social influence, facilitating conditions and habit) having a direct positive effect, and two (hedonic motivation and price-value) having no effect on the dependent variable. Therefore, H1, H2, $\mathrm{H} 3, \mathrm{H} 4$ and $\mathrm{H} 7$ are supported, and $\mathrm{H} 5$ and $\mathrm{H} 6$ are not supported.

\section{Conclusions and discussion}

It has been recognised that tourists are the perfect buyers to revitalise on-site shopping (García-Milon et al., 2021; Lindberg et al., 2019; Rabbiosi, 2015). Tourists use different sources of information to reduce their feelings of uncertainty and lack of awareness of the shopping process in unfamiliar destinations (García-Milon et al., 2019). The importance of this lies in the fact that the sources of information consulted are the tourist's first contact with the destination, so they can increase or decrease his/her purchase intentions (Gursoy and McCleary, 2004) and shape the shopping experience. Given that tourists possess the technologies to inform themselves when visiting destinations, the UTAUT2 model has been applied to understand the tourists' acceptance of these technologies, and their intention to use digital sources of information in their purchases at destinations.

Tourists today seek information from different technological devices to make their purchases. So, what theoretical background explains their motivation to do so? It has been 
established that the factors that influence the tourist's intention to use digital sources of information are, in order of importance, performance expectancy, habit, effort expectancy, social influence and facilitating conditions.

First, as H1 shows, performance expectancy is an essential factor in the use of digital sources of information. Previous studies have also found it is important in the adoption of new technologies, such as mobile banking (Alalwan et al., 2017) and in the acceptance of Etourism (Herrero et al., 2017; Ibukun et al., 2016). It has also been considered the most important factor in the adoption of mobile applications by tourists (Gupta et al., 2018) and in technological location-based services in tourism (Uphaus et al., 2019). It has been confirmed that, if tourists perceive that it is advantageous and useful to draw on information sources, they are motivated to use them at destinations because this helps them make better decisions, improving performance.

Habit leads tourists to use digital information sources in their purchases and has a positive effect on use intention. The results obtained are consistent with previous studies on intention to use Near-Field Communications (NFC) to make mobile payments in hotels (Morosan and DeFranco, 2016). Habit has also been found to be important in other technological uses in various tourism activities (e.g. Cássia de Moura et al., 2017; Castañeda et al., 2019). In addition, the more normal the use of information sources becomes, the more frequently they will be used. Thus, tourists who already are in the habit of regularly using sources of information are more likely to use them in the future.

Another supported hypothesis regards effort expectancy, that is, the degree of ease that the tourist associates with the use of information sources. This has been found to be a significant factor in predicting behaviour in technological innovations in mobile banking (Alalwan et al., 2017; Baptista and Oliveira, 2015), in education (Raman and Don, 2013) and in tourism (Ibukun et al., 2016; Uphaus et al., 2019). In our case, we found that tourists are more predisposed to use digital information sources to make purchases in a destination if they are easy to manage and do not require much effort.

$\mathrm{H} 3$ suggests that social influence makes tourists consider the opinions of others when they use sources of information to make their purchases. The results revealed that others' views are, indeed, important and, therefore, the opinions of the people around the tourist affect his/ her intention to use sources of information. This was not seen as significant in the acceptance and use of mobile banking (Alalwan et al., 2017; Baptista and Oliveira, 2015) but was considered an important factor in the acceptance of new information and communication technologies (Macedo, 2017; Venkatesh et al., 2003, 2012). Regarding its role in the acceptance of technological applications in tourism, some studies have supported its influence (e.g. Gupta et al., 2018) and others have not (e.g. Uphaus et al., 2019).

The facilitating conditions associated with digital information sources support the tourist in making his/her purchases. As H4 has been supported, we can conclude that tourists need to have the knowledge, resources and support to use the digital information sources available; it has been shown that this affects use intention. In the field of E-tourism, it has been found that facilitating conditions are an influential factor in technology acceptance (Ibukun et al., 2016). They have also been considered as an important predictor (Raman and Don, 2013) of the acceptance of educational management systems in teaching and in tourism (Ibukun et al.,2016).

$\mathrm{H} 5$ and $\mathrm{H} 6$ were not supported. The influence of hedonic motivation and price-value on intention to use sources of information to buy was ruled out. The price-value results are in line with other studies that show that its influence on the behavioural intention of consumers when using new technologies is not significant (e.g. Baptista and Oliveira, 2015; Macedo, 2017). However, the hedonic motivation result contradicts previous studies (e.g. Baptista and Oliveira, 2015; Ibukun et al., 2016; Macedo, 2017; Morosan and DeFranco, 2016; Raman and Don, 2013; Uphaus et al., 2019; Venkatesh et al., 2012) that found it to be a good indicator of behavioural intention. Our research results suggest that utilitarian motivations do explain 
EJMBE 30,2 intention to use digital information sources, while hedonic motivations do not. This lack of hedonic motivation could be caused by the nature of the search for information which is mainly functional, as a result, hedonism is not a predictor of this tourists' technological behaviour. Price has no effect, mainly because the digital information sources commonly available to tourists, particularly since the Internet has become almost universal, are free or low cost. Therefore, tourists do not perceive price as an important element in their intention to use this type of information sources.

\section{Theoretical implications}

This paper contributes to the scarce literature on intention to use digital information sources in tourist shopping, this practice is important since it is the first step of the tourist shopping journey at the destination. While some previous studies have highlighted the need for research into the influence of technological developments on tourist shopping, given its importance in the tourism context (e.g. Jin et al., 2017), little academic attention has been paid to this specific activity. Thus, this paper represents an initial contribution to the understanding of the tourist's on-site purchase behaviour and his or her tourist shopping journey in a digital context.

The most important contribution of this work is that the most relevant driver of the intention to use digital information sources in tourist shopping is utilitarian, that is, performance expectancy. This result is different from Goossens (2000) who highlighted the importance of both hedonic and utilitarian aspects in tourists' behaviour, suggesting that emotional factors are more important than utilitarian. Therefore, any future model that combines tourist shopping and technology should consider the utilitarian aspect.

Furthermore, the other main predictors for tourist's intention to use digital sources of information when shopping in a destination, in order of relevance, are habit, effort expectancy, social influence and facilitating conditions. Especially, habit has demonstrated its explicative capacity in this digital context which reinforces its accurate integration into the model (Venkatesh et al., 2012) compared to its antecedent UTAUT (Venkatesh et al., 2003). However, it must be highlighted that although in this specific practice, tourists are influenced by the majority of the UTAUT2 factors, hedonic motivation and price-value were not significant and were ruled out from the model.

A further implication is that this study supports the versatility of the UTAUT2 model for diverse technological contexts. It can be successfully tested for entirely technological activities but also for supportive or secondary practices of a non-technological activity, such as, in this case, tourist shopping. This work represents a step forward in research for employing the model in activities where technology is not the executing element, but a support resource.

\section{Managerial implications}

Understanding why tourists intend to use digital information sources is a key because it relates to the start of the tourist shopping journey. This is especially important in tourism, because tourists are generally unfamiliar with their destinations and what possibilities they offer. Thus, if retailers and destinations do not have digital information sources suitable for their target market, they may face a drastic reduction in visibility and, consequently, sales. The results obtained provide a series of practical implications for destinations, retail stores and businesses regarding tourists' shopping information-search processes and motivations behind their intention to use digital information sources such as social networks, forums, search engines, etc.

First, the tourist's perception of the usefulness of an information source must be high for it to encourage him/her to begin shopping. Tourists have limited time and want to optimise it in 
their shopping activity. Therefore, their information search processes must provide advantages, be useful and improve their performance of the activity (Castañeda et al., 2019); otherwise, the purchasing process will not begin. Understanding their search objectives is crucial for providing the best possible service. Moreover, the tourist must believe that using sources of information will improve his/her performance; searching for information will therefore become a habit and a natural part of the shopping process.

It has been shown that digital information source designers need to develop hedonic features when utilitarian systems are insufficient to persuade users to accept a technology (Tamilmani et al., 2019). In our case, the information search activity, far from being hedonic, is mainly functional. Although purchases in themselves are seen as being hedonic, the task of seeking information, even if it is to facilitate a purchase, has a utilitarian purpose. This is because using information sources improves results and efficiency, and thus helps the consumer to be more productive (Pahnila and Warsta, 2010).

It is also imperative that destinations and businesses have well-designed digital information platforms that are intuitive to use and involve minimal consumer effort (Vijayasarathy, 2003). In this respect, following the structure of existing information sources that have high rates of consumer usage will reduce tourists' learning efforts (and foster standardisation). Moreover, the Internet must be provided by destinations and easily accessible to tourists. Also, technical and human support must be provided, and suppliers must resolve tourists' doubts; this will add value to the information sources and should increase their use by tourists. Our results showed that tourists are influenced by their social environment, for example, relatives, friends and/or the famous, when making decisions about the technologies they use to seek information. Therefore, an effective way to encourage the use of particular digital information sources would be to influence the attitude of this social environment.

Furthermore, the new coronavirus disease 2019 (COVID-19) context means that tourists' activities will, in future, be based more on contactless interactions (O'Leary, 2020). Therefore, it is important for destination managers to provide suitable digital sources of information to help tourists begin the buying process at destinations while respecting social distancing.

\section{Limitations and future lines of research}

As the use of digital information sources is not static, and this study takes account of only the search stage at the point the tourists arrived, this research could be replicated at other points in the tourists' shopping journey. It could also be expanded to other cities and countries to test if the results differ from those obtained in this paper.

An interesting question, not posed in this study, is the issue of repeat visits to the same destination, as this may affect intention to use sources of information, based on whether the tourist is already familiar with the destination. This data could be incorporated into future, related studies. Another possible enhancement would be to connect intention to use digital information sources to shop at a destination with actual technological behaviours, level of purchase intention and even with completed purchases. Other issues such as the actual use of digital sources before the trip or tourists' ages could be considered in future studies. In addition, it may be that there is a relation between increased levels of shopping, in terms of volume/value, and the use of information sources. It would be interesting to identify, in this case, the type of sources used.

Given that this research is quantitative, it could be enhanced by a qualitative assessment of sources of information usage by tourist shoppers. Also, other theories, such as risk perception and rational decision-making, could be applied in a similar study. In addition, future studies could consider UTAUT2 moderators in the conceptualisation and analysis. Another research line could focus on specific types of tourist purchases (e.g. compulsive 
EJMBE 30,2

\section{6}

purchases, cross shopping, high-involvement purchases, low-involvement purchases, emergency purchases and impulse buying).

Finally, on March 11, 2020, the World Health Organization (WHO) declared the global pandemic COVID-19 that has paralysed economies, tourism and tourist purchases; therefore, it is necessary to continue researching in this field, advancing theory and practice. This will help overcome the situation and provide solutions for destination managers.

\section{References}

Ajzen, I. (1991), "The theory of planned behavior", Organizational Behavior and Human Decision Processes, Vol. 50 No. 2, pp. 179-211, doi: 10.1016/0749-5978(91)90020-T.

Ajzen, I. and Fishbein, M. (2005), "The influence of attitudes on behavior”, Journal of Social Psychology, Vol. 44 No. 1, pp. 115-127, doi: 10.1080/00224545.1956.9921907.

Akalamkam, K. and Mitra, J.K. (2018), "Consumer pre-purchase search in online shopping: role of offline and online information sources", Business Perspectives and Research, Vol. 6 No. 1, pp. 1-19, doi: 10.1177/2278533717730448.

Alalwan, A.A., Dwivedi, Y.K. and Rana, N.P. (2017), "Factors influencing adoption of mobile banking by Jordanian bank customers: extending UTAUT2 with trust", International Journal of Information Management, Vol. 37 No. 3, pp. 99-110, doi: 10.1016/j.ijinfomgt.2017.01.002.

Baptista, G. and Oliveira, T. (2015), "Understanding mobile banking: the unified theory of acceptance and use of technology combined with cultural moderators", Computers in Human Behavior, Vol. 50, pp. 418-430, doi: 10.1016/j.chb.2015.04.024.

Brochado, A., Oliveira, C., Rita, P. and Oliveira, F. (2018), "Shopping centres beyond purchasing of luxury goods: a tourism perspective”, Annals of Leisure Research, Vol. 22 No. 4, pp. 484-505, doi: 10.1080/11745398.2018.1522594.

Brown and Venkatesh (2005), "Model of adoption of technology in households: a baseline model test and extension incorporating household life cycle", MIS Quarterly, Vol. 29 No. 3, p. 399, doi: 10. $2307 / 25148690$.

Cássia de Moura, A., De Sevilha Gosling, M., Magalhães Christino, J.M. and Borges Macedo, S. (2017), "Acceptance and use of technology by older adults for choosing a tour-ism destination: a study using UTAUT2", Revista Brasileira de Pesquisa Em Turismo, Vol. 11 No. 2, p. 239, doi: 10.7784/ rbtur.v11i2.1277.

Castañeda, J-A., Martínez-Heredia, M.-J. and Rodriguez-Molina, M. (2019), "Explaining tourist behavioral loyalty toward mobile apps", Journal of Hospitality and Tourism Technology, Vol. 10, pp. 415-430, doi: 10.1108/JHTT-08-2017-0057.

Chang, J., Yang, B.T. and Yu, C.G. (2006), "The moderating effect of salespersons' selling behaviour on shopping motivation and satisfaction: taiwan tourists in China", Tourism Management, Vol. 27 No. 5, pp. 934-942, doi: 10.1016/j.tourman.2005.06.001.

Chen, R.J.C. (2013), "How can stores sustain their businesses? From shopping behaviors and motivations to environment preferences", Sustainability (Switzerland), Vol. 5 No. 2, pp. 617-628, doi: 10.3390/su5020617.

Childers, T., Carr, C., Peck, J. and Carson, S. (2001), "Hedonic and utilitarian motivations for online retail shopping behavior hedonic and utilitarian motivations for online retail", Journal of Retailing, Vol. 77 Winter, pp. 511-535, doi: 10.1016/S0022-4359(01)00056-2.

Chin, W.W. (1998), "The partial least squares approach to structural equation modelling", Modern Methods for Business Research, Vol. 1998 January, pp. 295-336.

Choi, M.J., Heo, C.Y. and Law, R. (2016), "Progress in shopping tourism", Journal of Travel and Tourism Marketing, Vol. 33 April, pp. S1-S24, doi: 10.1080/10548408.2014.969393.

Cohen, S.A., Prayag, G. and Moital, M. (2014), "Consumer behaviour in tourism: concepts, influences and opportunities", Current Issues in Tourism, Vol. 17 No. 10, pp. 872-909, doi: 10.1080/ 13683500.2013.850064. 
Coresight Research (2020), Retail Store Databank, Coresight Research.

Coromina, L. and Camprubí, R. (2016), "Analysis of tourism information sources using a Mokken Scale perspective”, Tourism Management, Vol. 56, pp. 75-84, doi: 10.1016/j.tourman.2016.03.025.

Davis, Bagozzi, R. and Warshaw, P. (1989), "User acceptance of computer technology: a comparison of two theoretical models", Management Science, Vol. 35 No. 8, pp. 982-1003, doi: 10.2307/2632151.

Ditrendia (2018), "Informe ditrendia: mobile en España y en el Mundo 2018”, Ditrendia, pp. 1-106.

Dodds, W.B. (1991), "In search of value: how price and store name information influence buyers' product perceptions", Journal of Consumer Marketing, Vol. 8 No. 2, pp. 15-24, doi: 10.1108/ 07363769110034974.

EFE, A. (2016), "Lucronium apuesta por lograr que Logroño sea Ciudad Comercial de Europa 2020 ABC.es - noticias Agencias", available at: http://agencias.abc.es/agencias/noticia.asp? noticia $=2290407$.

Escobar-Rodríguez, T. and Carvajal-Trujillo, E. (2014), "Online purchasing tickets for low cost carriers: an application of the unified theory of acceptance and use of technology (UTAUT) model", Tourism Management, Vol. 43, pp. 70-88, doi: 10.1016/j.tourman.2014.01.017.

Fritz, W., Sohn, S. and Seegebarth, B. (2017), "Broadening the perspective on mobile marketing: an introduction", Psychology and Marketing, Vol. 34 No. 2, pp. 113-118, doi: 10.1002/mar.20978.

García-Milon, A., Juaneda-Ayensa, E., Olarte-Pascual, C. and Pelegrín-Borondo, J. (2019), "Tourist shopping and omnichanneling", in Teixeira, S. and Ferreira, J. (Eds), Multilevel Approach to Competitiveness in the Global Tourism Industry, IGI Global, pp. 87-97, doi: 10.4018/978-1-79980365-2.ch006.

García-Milon, A., Juaneda-Ayensa, E., Olarte-Pascual, C. and Pelegrín-Borondo, J. (2020), "Towards the smart tourism destination: key factors in information source use on the tourist shopping journey", Tourism Management Perspectives, Vol. 36 October, doi: 10.1016/j.tmp. 2020.100730 .

García-Milon, A., Pelegrín-Borondo, J., Juaneda-Ayensa, E. and Olarte-Pascual, C. (2021), "The smartphone: the tourist's on-site shopping friend. An extended cognitive, affective, normative model", Telematics and Informatics, Vol. 61, doi: 10.1016/j.tele.2021.101618.

Goossens, C. (2000), "Tourism information and pleasure motivation", Annals of Tourism Research, Vol. 27 No. 2, pp. 301-321, doi: 10.1016/S0160-7383(99)00067-5.

Gupta, A., Dogra, N. and George, B. (2018), "What determines tourist adoption of smartphone apps?: an analysis based on the UTAUT-2 framework", Journal of Hospitality and Tourism Technology, Vol. 9 No. 1, pp. 48-62, doi: 10.1108/JHTT-02-2017-0013.

Gursoy, D. and McCleary, K.W. (2004), "An integrative model of tourists' information search behavior", Annals of Tourism Research, Vol. 31 No. 2, pp. 353-373, doi: 10.1016/j.annals.2003.12.004.

Hair, J.F., Ringle, C.M. and Sarstedt, M. (2011), "PLS-SEM: indeed a silver bullet”, The Journal of Marketing Theory and Practice, Vol. 19 No. 2, pp. 139-152, doi: 10.2753/MTP1069-6679190202.

Hair, J.F., Ringle, C.M. and Sarstedt, M. (2013), "Partial least squares structural equation modeling: rigorous applications, better results and higher acceptance", Long Range Planning, Vol. 46 Nos 1-2, pp. 1-12, doi: 10.1016/j.lrp.2013.01.001.

Henseler, J. (2018), "Partial least squares path modeling: quo vadis?", Quality and Quantity, Vol. 52 No. 1, pp. 1-8, doi: 10.1007/s11135-018-0689-6.

Herrero, Á., San Martín, H. and Garcia-De los Salmonesdel, M.M. (2017), "Explaining the adoption of social networks sites for sharing user-generated content: a revision of the UTAUT2", Computers in Human Behavior, Vol. 71, pp. 209-217, doi: 10.1016/j.chb.2017.02.007.

Hsieh, A.T. and Chang, J. (2006), "Shopping and tourist night markets in Taiwan", Tourism Management, Vol. 27 No. 1, pp. 138-145, doi: 10.1016/j.tourman.2004.06.017.

Ibukun, E., Okuboyejo, S.R. and Kelechi, A. (2016), "The adoption of E-tourism: an empirical investigation”, Asian Journal of Information Technology, Vol. 15 No. 18, pp. 3422-3429.

purchases in a destination 
EJMBE 30,2

Jansen-Verbeke, M. (1991), "Leisure shopping. A magic concept for the tourism industry?", Tourism Management, Vol. 12 No. 1, pp. 9-14, doi: 10.1016/0261-5177(91)90024-N.

Jin, H., Moscardo, G. and Murphy, L. (2017), "Making sense of tourist shopping research: a critical review”, Tourism Management, Vol. 62, pp. 120-134, doi: 10.1016/j.tourman.2017.03.027.

Koo, C., Gretzel, U., Hunter, W.C. and Chung, N. (2015), “The role of IT in tourism”, Asia Pacific Journal of Information Systems, Vol. 25 No. 1, pp. 99-104, doi: 10.14329/apjis.2015.25.1.099.

Kozak, M., Rita, P. and Bigné, E. (2018), "New frontiers in tourism: destinations, resources, and managerial perspectives", European Journal of Management and Business Economics, Vol. 27 No. 1, pp. 2-5, doi: 10.1108/EJMBE-03-2018-066.

Lee, H., Chung, N. and Nam, Y. (2019), "Do online information sources really make tourists visit more diverse places?: based on the social networking analysis", Information Processing and Management, Vol. 56 No. 4, pp. 1376-1390, doi: 10.1016/j.ipm.2018.01.005.

Lindberg, M., Johansson, K., Karlberg, H. and Balogh, J. (2019), "Place innovative synergies for city center attractiveness: a matter of experiencing retail and retailing experiences", Urban Planning, Vol. 4 No. 1, pp. 91-105, doi: 10.17645/up.v4i1.1640.

Lloyd, A.E., Yip, L.S.C. and Luk, S.T.K. (2011), "An examination of the differences in retail service evaluation between domestic and tourist shoppers in Hong Kong", Tourism Management, Vol. 32 No. 3, pp. 520-533, doi: 10.1016/j.tourman.2010.04.004.

Macedo, I.M. (2017), "Predicting the acceptance and use of information and communication technology by older adults: an empirical examination of the revised UTAUT2", Computers in Human Behavior, Vol. 75, pp. 935-948, doi: 10.1016/j.chb.2017.06.013.

Martin, B. and Mason, S. (1987), "Leisure and shopping”, Leisure Studies, Vol. 6 No. 1, pp. 93-97, doi: $10.1080 / 02614368700390081$.

Melero, I., Sese, F.J. and Verhoef, P. (2016), "Recasting the customer experience in today's omnichannel environment”, Universia Business Review, Vol. 50, pp. 18-37, doi: 10.3232/UBR.2016. V13.N2.01.

Montero, H. (2019), “El fin de las tiendas de barrio? 23 comercios cierran cada día. La Razón”, available at: https://www.larazon.es/economia/20191210/qg3lhmdksneg3dkejsgpci7icq.html.

Moore, G.C. and Benbasat, I. (1991), "Development of an instrument to measure the perceptions of adopting an information technology innovation", Information Systems Journal, Vol. 2 No. 3, pp. 192-222, doi: 10.1287/isre.2.3.192.

Morosan, C. and DeFranco, A. (2016), 'It's about time: revisiting UTAUT2 to examine consumers' intentions to use NFC mobile payments in hotels", International Journal of Hospitality Management, Vol. 53, pp. 17-29, doi: 10.1016/j.ijhm.2015.11.003.

Mosquera, A., Juaneda-Ayensa, E., Olarte-Pascual, C. and Pelegrín-Borondo, J. (2018), "Key factors for in-store smartphone use in an omnichannel experience: millennials vs nonmillennials", Complexity, Vol. 2018, pp. 1-14, doi: 10.1155/2018/1057356.

Nielsen (2014), "Estudio Nielsen sobre la evolución y tendencias del consumo de vino en España en 2014: Rioja fortalece su posición en el mercado de vinos de calidad revalorizando su oferta”, available at: https://es.riojawine.com/es/20-noticias/3414-estudio-nielsen-sobre-la-evolucion-ytendencias-del-consumo-de-vino-en-espana-en-2014-rioja-fortalece-su-posicion-en-el-mercado-devinos-de-calidad-revalorizando-su-oferta.html.

O'Leary, D.E. (2020), "Evolving information systems and technology research issues for COVID-19 and other pandemics", Journal of Organizational Computing and Electronic Commerce, Vol. 30 No. 1, pp. 1-8, doi: 10.1080/10919392.2020.1755790.

Pahnila, S. and Warsta, J. (2010), "Online shopping viewed from a habit and value perspective", Behaviour and Information Technology, Vol. 29 No. 6, pp. 621-632, doi: 10.1080/0144929X.2010. 501115.

Pan, S. and Jordan-Marsh, M. (2010), "Internet use intention and adoption among Chinese older adults: from the expanded technology acceptance model perspective", Computers in Human Behavior, Vol. 26 No. 5, pp. 1111-1119, doi: 10.1016/j.chb.2010.03.015. 
Piotrowicz, W. and Cuthbertson, R. (2014), "Introduction to the special issue information technology in retail: toward omnichannel retailing", International Journal of Electronic Commerce, Vol. 18 No. 4, pp. 5-16, doi: 10.2753/JEC1086-4415180400.

Rabbiosi, C. (2011), "The invention of shopping tourism. The discursive repositioning of landscape in an Italian retail-led case", Journal of Tourism and Cultural Change, Vol. 9 No. 2, pp. 70-86, doi: 10.1080/14766825.2010.549233.

Rabbiosi, C. (2015), "Renewing a historical legacy: tourism, leisure shopping and urban branding in Paris", Cities, Vol. 42, pp. 195-203, doi: 10.1016/j.cities.2014.07.001.

Raman, A. and Don, Y. (2013), "Preservice teachers' acceptance of learning management software: an application of the UTAUT2 model", International Education Studies, Vol. 6 No. 7, pp. 157-164, doi: 10.5539/ies.v6n7p157.

Rodríguez-Torrico, P., San José Cabezudo, R. and San-Martín, S. (2017), "Tell me what they are like and I will tell you where they buy. An analysis of omnichannel consumer behavior", Computers in Human Behavior, Vol. 68, pp. 465-471, doi: 10.1016/j.chb.2016.11.064.

Rodríguez-Torrico, P., Prodanova, J., San-Martín, S. and Jimenez, N. (2020), "The ideal companion: the role of mobile phone attachment in travel purchase intention", Current Issues in Tourism, Vol. 23 No. 13, pp. 1659-1672, doi: 10.1080/13683500.2019.1637828.

Shmueli, G., Ray, S., Velasquez Estrada, J.M. and Chatla, S.B. (2016), "The elephant in the room: predictive performance of PLS models", Journal of Business Research, Vol. 69 No. 10, pp. 4552-4564, doi: 10.1016/j.jbusres.2016.03.049.

Silva, R., Breda, Z., Brandão, F., Costa, R. and Costa, C. (2019), "Shopping tourism: a destination management perspective", Advances in Tourism, Technology and Smart Systems, pp. 477-487.

Tamilmani, K., Rana, N.P., Prakasam, N. and Dwivedi, Y.K. (2019), "The battle of Brain vs. Heart: a literature review and meta-analysis of 'hedonic motivation' use in UTAUT2", International Journal of Information Management, Vol. 46 No. February, pp. 222-235, doi: 10.1016/j.jinfomgt. 2019.01.008.

Thompson, R.L., Higgins, C.A. and Howell, J.M. (1991), "Personal computing: toward a conceptual model of utilization”, MIS Quarterly, Vol. 15 No. 1, p. 125, doi: 10.2307/249443.

Timothy, D.J. (2005), Shopping Tourism, Retailing, and Leisure, Channel View Publications, available at: https://books.google.es/books/about/Shopping_tourism_retailing_and_leisure.html? $\mathrm{id}=$ dfAJAQAAMAAJ\&redir_esc $=\mathrm{y}$.

Timothy, D.J. and Butler, R.W. (1995), "Cross-border shopping: a north American perspective”, Annals of Tourism Research, Vol. 22 No. 1, pp. 16-34.

Tosun, C., Temizkan, S.P., Timothy, D.J. and Fyall, A. (2007), "Tourist shopping experiences and satisfaction”, International Journal of Tourism Research, Vol. 9 No. 2, pp. 87-102, doi: 10.1002/ jtr.595.

Uphaus, P.O., Ehlers, A. and Rau, H. (2019), "Location-based services in tourism: an empirical analysis of factors influencing usage behaviour", European Journal of Tourism Research, Vol. 23 November, pp. 6-27.

Venkatesh, V. and Davis (2000), "A theoretical extension of the technology acceptance model: four longitudinal field studies", Management Science, Vol. 46 No. 2, pp. 186-204, doi: 10.1287/mnsc. 46.2.186.11926.

Venkatesh, Davis, M. and Davis (2003), "User acceptance of information technology: toward a unified view”, MIS Quarterly, Vol. 27 No. 3, p. 425, doi: 10.2307/30036540.

Venkatesh, V., Thong, J.Y.L. and $\mathrm{Xu}, \mathrm{X}$. (2012), "Consumer acceptance and use of information technology : extending the unified theory”, MIS Quarterly, Vol. 36 No. 1, pp. 157-178, doi: 10. 1017/CBO9781107415324.004.

Verdegem, P. and De Marez, L. (2011), "Rethinking determinants of ICT acceptance: towards an integrated and comprehensive overview", Technovation, Vol. 31 No. 8, pp. 411-423, doi: 10.1016/ j.technovation.2011.02.004. purchases in a
destination 
EJMBE 30,2

Verhoef, P.C., Kannan, P.K. and Inman, J.J. (2015), "From multi-channel retailing to omni-channel retailing. Introduction to the special issue on multi-channel retailing", Journal of Retailing, Vol. 91 No. 2, pp. 174-181, doi: 10.1016/j.jretai.2015.02.005.

Vijayasarathy, L.R. (2003), "Predicting consumer intentions to use on-line shopping: the case for an augmented technology acceptance model", Information and Management, Vol. 41 No. 6, pp. 747-762, doi: 10.1016/j.im.2003.08.011.

Way, K.A. and Robertson, L.J. (2013), "Shopping and tourism patterns of attendees of the bikes, blues \& BBQ festival", Journal of Hospitality Marketing and Management, Vol. 22 No. 1, pp. 116-133, doi: 10.1080/19368623.2012.627261.

Wong, I.K.A. and Wan, Y.K.P. (2013), "A systematic approach to scale development in tourist shopping satisfaction: linking destination attributes and shopping experience", Journal of Travel Research, Vol. 52 No. 1, pp. 29-41, doi: 10.1177/0047287512457263.

Yüksel, A. (2007), "Tourist shopping habitat: effects on emotions, shopping value and behaviours", Tourism Management, Vol. 28 No. 1, pp. 58-69, doi: 10.1016/j.tourman.2005.07.017.

\section{Corresponding author}

Alba García-Milon can be contacted at: algarcm@unirioja.es

For instructions on how to order reprints of this article, please visit our website:

www.emeraldgrouppublishing.com/licensing/reprints.htm

Or contact us for further details: permissions@emeraldinsight.com 